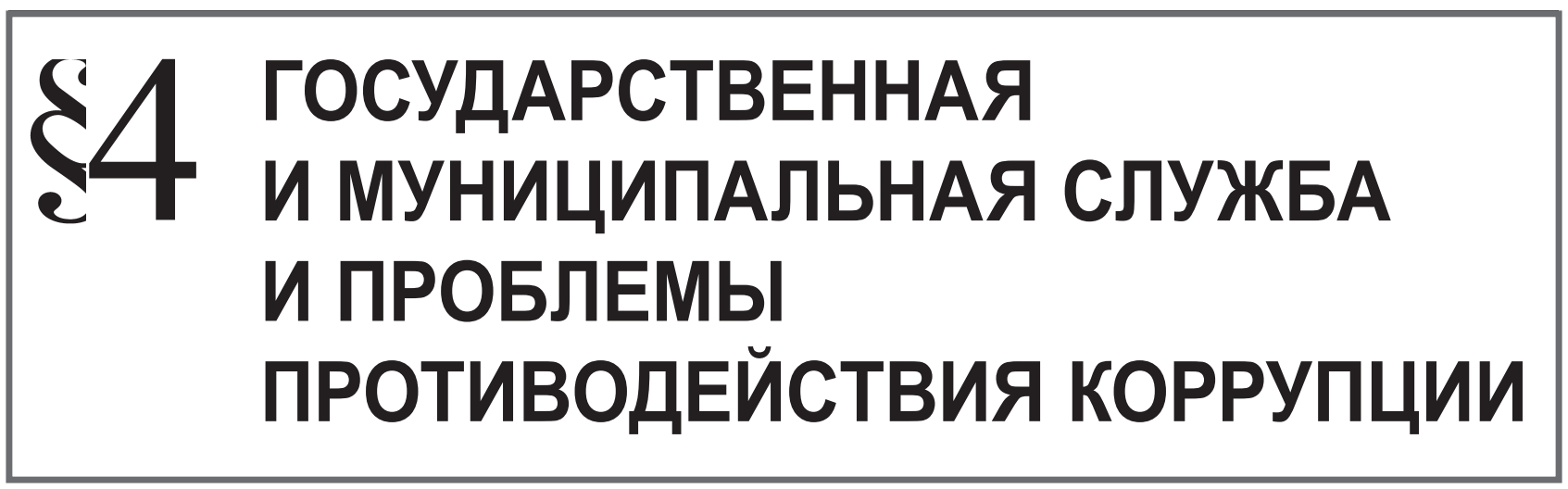

А.В. Куракин

\title{
МЕЖДУНАРОДНО-ПРАВОВЫЕ ИСТОЧНИКИ АДМИНИСТРАТИВНОГО ПРАВА В СФЕРЕ ПРОТИВОДЕЙСТВИЯ КОРРУПЦИИ В СИСТЕМЕ ГОСУДАРСТВЕННОЙ СЛУЖБЫ РОССИЙСКОЙ ФЕДЕРАЦИИ
}

$\mathrm{B}$ настоящее время без упоминания о коррупции не обходится практически ни один официальный документ, который посвящен социальноэкономическому и политическому развитию страны или борьбе с преступностью. Проблеме коррупции было уделено отдельное внимание и в Послании Президента Федеральному Собранию РФ в 2012 г. Однако от всеобщего обсуждения и осуждения проблемы коррупции, признание ее отрицательного воздействия на экономику, предпринимательство, развитие инвестиционного процесса, а также социальной инфраструктуры государства эта проблема, к сожалению, не решается. Принятое антикоррупционное законодательство пока еще не принесло ожидаемых результатов в деле противодействия коррупционным правонарушениям. Согласно данным Transparency International, в индексе восприятия коррупции в 2012 г. Россия набрала 28 баллов и заняла 133 место из 176 возможных. В рейтинге правовых государств, составленном независимой организацией World Justice Project, Россия заняла 85 -е место из $97^{1}$.

Как отмечают эксперты фонда ИНДЕМ - коррупция главный и динамично растущий сектор российской

1 Cм.: http://transparency.org.ru/indeks-vospriiatiia-korruptcii/ rossiia-v-indekse-vospriiatiia-korruptcii-2012-novaia-tochkaotscheta (дата обращения 27.01.2013). экономики, она преследует любой бизнес от регистрации до его захвата чиновниками или разорения. Годовой доход от коррупции более чем в два раза превысил суммарный доход от экспорта сырой нефти, нефтепродуктов и газа. Коррупция в России из эпизодического отклонения от моральных и юридических правил превратилась в несущую конструкцию власти, норму взаимоотношений граждан, бизнеса и государства ${ }^{2}$.

Следует признать, что высокий уровень коррупции на всех уровнях государственной власти и управления сдерживает развитие нашей страны, препятствует развитию экономики, представляет угрозу национальной безопасности. Как показывают многие социологические, экономические и правовые исследования, а также экспертные оценки в настоящее время в России на оплату услуг чиновников коммерсанты затрачивают от 20 до 50\% своей прибыли. Более половины западных бизнесменов отмечают, что в странах Восточной Европы взятка обычная практика, более $80 \%$ из них сказали, что полученные за взятки бюрократические услуги целиком окупили их затраты ${ }^{3}$.

\footnotetext{
См.: Левин М., Сатаров Г. Коррупция в России: классификация и динамика // Вопросы экономики. - 2012. - №10. - С. 4.

См.: Лукашук И.И. Международно-правовые формы борьбы с коррупцией // Коррупция: политические, экономические, организационные и правовые проблемы. - М., 2001. - С. 84.
} 
С проблемой коррупции тесно взаимосвязана проблема административного давления на бизнес. По данным международной консалтинговой компании «Грант Торнтон» давление чиновников на предпринимателей за последние годы в Российской Федерации существенно усилилось. Вполне логично, что чем выше давление на бизнес, тем выше уровень коррупции. Вследствие этого продолжает снижаться конкурентно способность отечественной экономки, падает ее инвестиционная привлекательность. Согласно данным Всемирного экономического форума вследствие коррупции по инвестиционной привлекательности наша страна занимает 66-е место из 142. За несколько последних лет нас обогнали такие страны как Вьетнам, Латвия, Коста-Рика. Для улучшения конкурентоспособности среди прочих мер необходимо усилить борьбу с коррупцией и экономической преступностью, устранить необоснованные административные барьеры, улучшить работу органов управления в сфере экономки ${ }^{4}$.

Следует сказать, что членство РФ в ряде международных организаций возлагает на нее многие международно-правовые обязательства, в том числе и в сфере борьбы с коррупцией в системе государственной службы. Подтверждение этому ратификация в 2006 г. Конвенции Организации Объединенных Наций против коррупции ${ }^{5}$. В этой связи одним из приоритетных направлений в исследовании проблем борьбы с коррупцией в системе государственной службы РФ является изучение норм международного права содержащих в себе административно-правовые средства ее предупреждения и пресечения. Необходимость использования международных средств предупреждения и пресечения коррупции в системе государственной службы, по мнению Т.М. Виноградской объясняется тем, что «эффективная борьба с коррупцией невозможна только в рамках национального законодательства, так как эти правонарушения носят межнациональный характер»

В этой связи для реализации административноправовых средств предупреждения и пресечения коррупции в системе государственной службы РФ

4 См.: Гришковец А.А. К вопросу о реформе государственной службы (организационно-правовые аспекты) // Государство и право. - 2012. - № 2. - С. 25.

5 Федеральный закон от 8 марта 2006 г. «О ратификации Конвенции Организации Объеденных Наций против коррупции» // Российская газета. - 2006. - 21 марта.

6 См.: Виноградская Т.М. Совершенствование законодательства самая дешевая и эффективная мера снижения коррумпированности // Борьба с коррупцией: актуальные проблемы законодательного обеспечения. - М., 2002. - С. 92-97. необходимо совершенствовать механизмы международного сотрудничества, целенаправленно применять международно-правовые документы, содержащие в себе предписания направленные на борьбу с коррупций.

Как отмечает С.В. Поленина «активизация взаимодействия международной и национальной правовых систем - одна из характерных черт современного мира» ${ }^{7}$.

Согласно Конституции России, а также действующему законодательству международные договоры являются одним из важнейших средств развития международного сотрудничества, способствуют расширению международных связей с участием государственных и негосударственных организаций, в том числе с участием субъектов национального права. Кроме этого международным договорам (конвенциям) принадлежит первостепенная роль в сфере защиты прав человека, обеспечения правопорядка, а также борьбе с коррупцией в системе государственной службы.

Как отмечает Л.А. Сергиенко «роль международно-правовых источников наиболее существенна в тех областях и сферах административно-правового регулирования, где в большей степени необходимо согласование национального и международного права» ${ }^{8}$.

Одним из приоритетных направлений, где необходимо объединение усилий международного и европейского сообщества является борьба с коррупцией в системе государственной службы. В этой сфере может осуществляться ряд правовых и организационных мероприятий:

- проведение научных исследований проблемы коррупции, осуществление взаимных консультации по проблеме борьбы с коррупцией. Консультации по проблеме национальной и международной коррупции помогали бы государствам в объединении усилий в вопросе предупреждения и пресечения коррупции в системе государственной службы;

- составление банков данных о национальных законах, формах, методах, средствах предупреждения и пресечения коррупции в системе государственной службы;

- оказание содействия в подборе и подготовке кадров, которые могли бы участвовать в мероприятиях по борьбе с коррупцией, а также разработке

\footnotetext{
См.: Поленина С.В. Законотворчество в Российской Федерации. - М., 1996. - С. 28.

8 См.: Сергиенко Л.А. Международно-правовые источники административного права // Административное и информационное право. - М., 2003. - С. 17.
} 
антикоррупционных стандартов поведения государственных служащих и проведения антикоррупционных экспертиз правовых норм и др. ${ }^{9}$

Исследование показывает, что в ряде международно-правовых актах Организации Объединенных Наций, Всемирного банка, Международного валютного фонда, Всемирной торговой организации, Европейского союза, Интерпола, Содружества Независимых Государств и других международных организаций отмечается, что коррупция представляет собой явление, которое в настоящее время выходит за пределы национальных границ и затрагивает все общества и экономические системы ${ }^{10}$.

Важным аспектом на пути развития международно-правовых средств предупреждения и пресечения коррупции в системе государственной службы, является признание того факта, что проблема коррупции касается незаконного отмыванию денежных средств, а также финансирования терроризма. Международное сообщество с каждым годом все больше беспокоит проблема стремительного обогащения высокопоставленных должностных лиц и членов их семей, особенно должностных лиц, занимающих высокие посты, как в международных организациях, так и в соответствующих государствах.

Названные и ряд иных обстоятельств говорят об объективной необходимости осуществления международного сотрудничества в сфере предупреждения и пресечения коррупции ${ }^{11}$.

Несмотря на то, что международное сообщество стремится к созданию универсальных правовых и организационных механизмов предупреждения и пресечения коррупции ряд государств не имеют самых простых национальных правовых и организационных средств предупреждения и пресечения коррупции в системе государственной службы. Данный факт способствует развитию коррупции не только в соответствующем государстве, но и в сопредельных государствах, а также международных организациях.

В настоящее время международное сообщество убеждено в актуальности проведения согласованной

9 См.: Раймонд Е. Кендалл. Вклад Интерпола в борьбу с коррупцией // Переводы материалов о практике деятельности правоохранительных органов зарубежных стран: ГИЦ МВД РФ. - М., 2004. - № 28. - С. 41.

10 См.: Коррупция и бюрократизм: истоки и пути преодоления. - М., 1998.

11 См.: Швец Е.В. Контроль за имущественным состоянием, доходами и обязательствами чиновников (международный и частноправовой аспекты) // Предупреждение организованной и коррупционной преступности средствами различных отраслей права. - М., 2002. - С. 206. политики, в сфере защиты общества от коррупции, развитии норм международного права в исследуемой сфере. Как уже отмечалось международная озабоченность проблемой коррупции, приводит к сотрудничеству государств в этой сфере. За последние десять лет состоялся ряд международных конгрессов, конференций и семинаров посвященных проблеме коррупции. Кроме этого в настоящее время принят ряд международно-правовых документов направленных на противодействие коррупции в сфере государственного управления, а также в системе государственной службы $^{12}$.

Принимаемые международным сообществом меры вызваны тем, что коррупция способствует нарушению прав человека, препятствует экономическому и социальному развитию государств и даже континентов, способствует формированию террористических организаций и т.п. Как мы может видеть не одно индустриально развитое государство не свободно от коррупции во многих государствах постоянно фиксируются факты, свидетельствующие об актуализации проблем борьбы с коррупцией, ведутся дискуссии о совершенствовании правовых средств предупреждения и пресечения коррупции в системе государственной службы и системе публичного управления (Италия, США, Германия, Франция и др.).

Несмотря на важность международно-правовых средств предупреждения и пресечения коррупции все же необходимо сказать, что для предупреждения и пресечения коррупции в системе государственной службы необходима эффективная работа национальной судебной и правоохранительной системы. Данное обстоятельство обусловлено тем, что акты коррупции совершатся на территории конкретного государства и если государство не будет само заинтересовано в выявлении коррупции и коррупционеров, то не помогут никакие международные и европейские средства борьбы с данным явлением. Социальная опасность коррупции проявляется в том, что коррупция способствует нарушению прав и законным интересов физических и юридических лиц, подрывает основы государственного строя, ведет к искажению правоприменения, а также наносит серьезный вред моральным основам общества $^{13}$.

В научной литературе много говориться, что для эффективного предупреждения и пресечения коррупции в системе государственной службы необходимо

12 См.: Меморандум правового комитета Совета Европы о борьбе с коррупцией // Коррупция и бюрократизм: истоки и пути преодоления. - М., 1998. - С. 5.

13 См.: там же. 
развивать международное сотрудничество, лучше применять имеющиеся конвенции и по мере надобности формировать необходимые административно-правовые средства национального характера. Глобальность проблемы коррупции в системе государственной службы способствовало тому, что международное сообщество с середины XX в. начинает разрабатывать правовые нормы и организационные средства, направленные на предупреждение и пресечение коррупции в сфере публичного управления и государственной службы.

В подтверждение этому можно привести ряд международных документов по данной проблематике: Международный кодекс поведения государственных должностных лиц (12 декабря 1996 г.), Декларация $\mathrm{OOH} \mathrm{«О} \mathrm{борьбе} \mathrm{с} \mathrm{коррупцией} \mathrm{и} \mathrm{взяточничеством} \mathrm{в}$ международных коммерческих операциях» (16 декабря 1996 г.), Международный Конвенция ООН против коррупции (31 октября 2003 г.), Резолюция ООН «Коррупция среди чиновников» (24 марта 1990 г.), Конвенция Совета Европы «Об уголовной ответственности за коррупцию» (27 января 1999 г.), Конвенция Совета Европы «О гражданско-правовой ответственности за коррупцию» (4 ноября 1999 г.), Модельный Закон «О борьбе с коррупцией» (постановление Межпарламентской Ассамблеи государств-участников СНГ от 3 апреля 1999 г. № 13-4).

На борьбу с коррупцией в правоохранительных органах направлены предписания таких документов как: Кодекс поведения должностных лиц по поддержанию правопорядка (17 декабря 1979 г.), Декларация о полиции (8 мая 1979 г.) и др. В этих актах осуждаются все виды коррупции, включая взяточничество, практикуемые транснациональными и другими корпорациями, их посредниками и другими причастными к этому сторонами в нарушении законов и правил принимающих сторон.

Несмотря на то, что Российская Федерация подписала, а некоторые из вышеназванных документов ратифицировала, тем не менее, на практике многие из вышеназванных документов игнорируются в российском законодательстве. Особенно показательно данная тенденция проявилась в связи с исключением из УК РФ в 2003 г. такового наказания как конфискация имущества за должностные преступления. Исключение из УК РФ конфискации как вида наказания нарушает ряд взятых РФ на себя обязательств, которые возникли в связи с подписанием ряда документов направленных на борьбу с коррупцией в системе государственной службы (Конвенции Совета Европы об уголовной ответственности за коррупцию, Международный Конвенция ООН против коррупции и др.).
Следует сказать, что в международно-правовых актах содержится широкое понимание коррупции. Коррупция понимается как корыстное использование или злоупотребление служебным положением в личных ли корпоративных интересах, таким образом, коррупция не сводиться к взяточничеству. Как отмечает Г.И. Богуш «узкое определение коррупции, как правило, используется для целей конкретного международно-правового документа» ${ }^{14}$. В справочном документе ООН о международной борьбе с коррупцией говорится, что «коррупция - это злоупотребление государственной властью для получения выгоды в личных целях».

Изучение ряда международных документов посвященных проблеме борьбы с коррупцией позволяет сказать, что в ряде из них содержится значительное количество норм административного права, которые регламентируют организационно-управленческие аспекты реализации этих соглашений. В частности нормами административного права регламентируются деятельность компетентных органов призванных вести борьбу с коррупцией, назначенных сторонами для выполнения соответствующего договора (конвенции), устанавливаются обязанности сторон по формированию смешанных управленческих структур, определяются формы и методы сотрудничества, в которых определяются необходимые виды управленческих действий. Устанавливаются правила или порядок совершения некоторых действий по выполнению соглашения (договора, конвенции $)^{15}$ и др.

Так Конвенция ООН о противодействии коррупции (31 октября 2003 г.) определяет, что каждое государство-участник стремится периодически проводить оценку соответствующих правовых документов и административных мер с целью определения их адекватности с точки зрения предупреждения коррупции и борьбы с ней.

Согласно Конвенции ООН каждое государствоучастник стремится, в надлежащих случаях и в соответствии с основополагающими принципами своей правовой системы, создавать, поддерживать и укреплять такие системы приема на работу, набора, прохождения службы, продвижения по службе и выхода

14 См.: Богуш Г.И. Понятие коррупции в международном праве и российском законодательстве // Вестник МГУ. Сер 11. Право. - 2004. - № 2. - С. 83.

15 См.: Сергиенко Л.А. Международно-правовые источники административного права // Административное и информационное право. - М., 2003. - С. 17; Виноградов В.А. О некоторых международно-правовых аспектах административного права // Административное право: теория и практика. - М., 2002. - С. 281. 
в отставку гражданских служащих и, в надлежащих случаях, других неизбираемых публичных должностных лиц, которые:

а) основываются на принципах эффективности и прозрачности и на таких объективных критериях, как безупречность работы, справедливость и способности;

b) включают надлежащие процедуры отбора и подготовки кадров для занятия публичных должностей, которые считаются особенно уязвимыми с точки зрения коррупции, и ротации, в надлежащих случаях, таких кадров на таких должностях;

c) способствуют выплате надлежащего вознаграждения и установлению справедливых окладов с учетом уровня экономического развития государстваучастника;

d) способствуют осуществлению образовательных и учебных программ, с тем, чтобы такие лица могли удовлетворять требованиям в отношении правильного, добросовестного и надлежащего выполнения публичных функций, а также обеспечивают им специализированную и надлежащую подготовку, с тем чтобы углубить осознание ими рисков, которые сопряжены с коррупцией и связаны с выполнением ими своих функций. Такие программы могут содержать ссылки на кодексы или стандарты поведения в применимых областях.

В сфере государственных закупок, управления публичными финансами, публичной отчетности государства, присоединившиеся к настоящей Конвенции, обязуется принимать такие гражданско-правовые и административные меры, какие могут потребоваться, в соответствии с основополагающими принципами его внутреннего законодательства, с тем, чтобы обеспечить сохранность бухгалтерских книг, записей, финансовых ведомостей или другой документации, касающейся публичных расходов и доходов, и воспрепятствовать фальсификации такой документации. Создавать упрощенные административные процедуры, а также публиковать информацию, которая может включать периодические отчеты об опасностях коррупции в публичной администрации.

Конвенция определяет административно-правовые и организационные механизмы сотрудничества государств в сфере борьбы с коррупцией в системе государственной службы. В частности в ней определяется механизм оказания содействия в расследовании и производстве по гражданско-правовым и административным вопросам, связанным с коррупцией, обмен информацией и координация административных и других мер, принимаемых с целью заблаговременного выявления преступлений коррупционного характера. В последние годы заметно активизировалось междуна- родное сотрудничество МВД, направленное, в том числе и на выявление и пресечение коррупционных преступлений. Взаимодействие с зарубежными коллегами осуществляется через представителей полицейских ведомств, аккредитованных при зарубежных посольствах в Москве, а также в рамках постоянно действующих рабочих групп с органами полиции Германии, США, Италии, Израиля, Турции и др. В ходе такого сотрудничества ФБР США проявили большой интерес к совместной работе по выявлению на территории США легализованных активов, принадлежащих некоторым российским гражданам, имевшим или имеющим отношение к государственной службе.

В 1989 г. под эгидой Организации Объединенных Наций прошел международный семинар по проблемам коррупции в сфере государственного управления, результаты которого послужили серьезной предпосылкой для рассмотрения этой проблемы на VIII конгрессе ООН. Предопределяя проект резолюции этому конгрессу, Экономический и Социальный Совет высказал следующую рекомендацию: «Поскольку коррупция среди государственных должностных лиц может свести на нет потенциальную эффективность всех видов правительственных программ, затруднить развитие и создать угрозу для отдельных лиц и групп людей, в высшей степени важно, чтобы все государства:

1) рассмотрели адекватность своего законодательства, включая процессуальные нормы, чтобы реагировать на все виды коррупции и соответствующие санкции, которые обеспечат соответствующее содержание;

2) разработали административные механизмы и механизмы регулирования для предупреждения коррупции и злоупотребления властью, которые должны включать: разработку стратегий по борьбе с коррупцией в качестве особо приоритетных направлений планов экономического и социального развития, которые бы включали элементы по борьбе с коррупцией как неотьемлемую часть соответствующих программ; повышение общественной осведомленности о праве пользоваться государственными услугами и программами и обеспечение эффективных каналов для подачи жалоб; создание надлежащих внутренних процедур управления в правительственных учреждениях для борьбы с коррупцией; принятие мер в рамках правительственных учреждений для обеспечения отчетности, эффективных дисциплинарных мер и средств правовой защиты в отношении государственных служащих; при необходимости совершенствование банковских и финансовых правил и механизмов в целях предупреждения крупных переводов, полученных в результате коррупции. 
3) установили процедуры выявления и расследования и осуждения коррумпированных должностных лиц;

4) разработали правовые положения для конфискации средств и имущества, приобретенных в результате коррупции и применяли экономические санкции предприятиям, причастным к коррупции» ${ }^{16}$.

Проблема борьбы с коррупцией специально обсуждалась и на VIII Конгрессе Организации Объединенных Наций по предупреждению преступности и обращению с правонарушителями (Гавана 1990 г.). В резолюции, озаглавленной «Коррупция в сфере государственного управления», конгресс одобрил подготовленные Секретариатом ООН руководство «Практические меры борьбы с коррупцией» и призвал обеспечить его широкое распространение.

Особую заинтересованность в международной борьбе с коррупцией проявил Совет Европы, подтверждением чему является принятие в ноябре 1996 г. программы действий по борьбе с коррупцией, а также резолюции о 20 руководящих принципах в борьбе с коррупцией (6 ноября 1997 г.). Которые комитет министров рекомендовал использовать всем государствам в целях содействия динамичному движению к эффективному предотвращению и борьбе с коррупцией.

В рамках вышеназванной программы Советом Европы были подготовлены: Конвенция об уголовной ответственности за коррупцию и Конвенция о гражданско-правовой ответственности за коррупцию. Особое место в их подготовке было уделено формулировкам понятий «коррупция», использованным в других документах, таких, как Конвенция Европейского союза о борьбе против коррупции должностных лиц Европейского сообщества и должностных лиц Европейского сообщества и должностных лиц государств - членов Европейского союза от 26 мая 1997 г. и Конвенции Организации экономического сотрудничества и развития о борьбе с подкупом иностранных должностных лиц при заключении международных коммерческих сделок от 17 декабря 1997 г. В ходе подготовки вышеупомянутых конвенций выявилось, что на сегодняшний день в определении коррупции нет полной ясности и правовой точности, в связи с чем было признано целесообразным рассматривать в Конвенции об уголовной ответственности за коррупцию 1998 г. понятие коррупции исходя из внутрен-

16 См.: Сайгитов У.Т. Коррупция как фактор организованной преступности в сфере экономики (криминологический анализ): дис. ... канд. юрид. наук. - Махачкала, 1998. - С. 18. него законодательства государств участников ${ }^{17}$, а в Конвенции о гражданско-правовой ответственности за коррупцию 1999 г. дать ее определение только для целей настоящей Конвенции.

Конвенция об уголовной ответственности за коррупцию принята в Страсбурге 4 ноября 1998 г. и открыта для подписания 27 января 1999 г. По состоянию на апрель 2006 г. ее подписали более 30 государств. Российская Федерация подписала ее в день открытия Конвенции для подписания на основании распоряжения Президента России от 25 января 1999 г. В настоящее время конвенция РФ ратифицирована.

Данная конвенция, состоящая из преамбулы и пяти глав: «Использование терминов», «Меры которые должны быть приняты на национальном уровне», «Контроль за выполнением конвенции», «Международное сотрудничество государств участников конвенции», «Заключительные положения», обеспечивает на основе общих элементов различных правовых подходов криминализацию широкого круга деяний, включая: составы активной и пассивной коррупции, объективная сторона которых совершена должностными лицами государств, иностранных государств, международных и национальных институтов, членами парламентов ассамблей, судьями; составы активного и пассивного взяточничества в сфере частного предпринимательства; торговлю влиянием; отмывание доходов, полученных от совершения актов коррупции, а также коррупцию в сфере аудита. Кроме того, она содержит другие нормы материального и процессуального права, касающиеся компетенции специализированных служб, ответственности юридических лиц, сотрудничества между ведомствами государств, защиты свидетелей.

Конвенция о гражданско-правовой ответственности за коррупцию 1999 г. принята в Страсбурге 9 сентября 1999 г. и открыта для подписания 4 ноября 1999 г. Сторонами Конвенции могут быть как государствачлены Совета Европы, так и государства, не являющиеся его членами, но участвовавшие в ее разработке. По состоянию на декабрь 2005 г. ее подписали 14 государств. Российская Федерация готовится подписать данную Конвенцию.

Конвенция 1999 г. состоит из преамбулы и трех глав: «Меры, которые должны быть приняты на национальном уровне», «Международное сотрудничество и контроль за выполнением», «Заключительные по-

\footnotetext{
17 См.: Максимов С.В. Проблемы и перспективы ратификации Россией Конвенции Совета Европы «Об уголовной ответственности за коррупцию» // Современная уголовная политика в сфере борьбы с транснациональной организованной преступностью и коррупцией. - М., 2002. - С. 129.
} 
ложения». В ней сформулировано такое определение «коррупции». Коррупция — означает, просьбу, предложение, дачу или получение, прямо или опосредованно взятки или любого другого ненадлежащего преимущества, или перспектив таковых, которые искажают нормальное выполнение любой обязанности, или поведение, требуемое от получателя взятки, ненадлежащего преимущества или перспектив таковых.

В Конвенции 1999 г. затронуты следующие аспекты:

- $\quad$ каждая сторона предусматривает в своем внутреннем законодательстве нормы, закрепляющие право лиц, понесших ущерб в результате коррупции, подать иск с целью получения полного возмещения ущерба;

- такое возмещение может охватить материальный ущерб, упущенную финансовую выгоду и нематериальный вред;

- каждая сторона предусматривает в своем внутреннем законодательстве следующие условия, которые должны быть выполнены для того, чтобы ущерб подлежал возмещению: ответчик совершил или не предпринял разумные шаги для предотвращения акта коррупции; истец понес ущерб; существует причинно-следственная связь между актом коррупции и нанесенным ущербом;

- каждая сторона определяет в своем внутреннем законодательстве надлежащие процедуры, позволяющие лицам, понесшим ущерб в результате акта коррупции, совершенного его публичными должностными лицами в ходе осуществления ими своих функций, требовать возмещения ущерба от государства или, в случае, если сторона не является государством, от соответствующих властей данной стороны; помимо этого, государства должны в своем внутреннем законодательстве предусматривать, что объем возмещения ущерба, уменьшается или в его возмещении может быть отказано, если истец по собственной вине способствовал причинению ущерба или его усугублению;

- $\quad$ каждая сторона предусматривает в своем внутреннем законодательстве, что любой контракт или положение контракта, предусматривающие совершение акта коррупции, являются недействительными и не имеющими юридической силы, а также надлежащую защиту от любой неоправданной меры служащих, которые имеют серьезные основания подозревать наличие коррупции и добросовестно сообщают о своем подозрении компетентным лицам и властям;

- каждая сторона в рамках своего внутреннего законодательства должна предусматривать необхо- димые меры для того, чтобы ежегодные отчеты компаний составлялись правильно и давали правдивое и честное представление о финансовом положении компании, а также устанавливать эффективные процедуры для получения доказательств в гражданством судопроизводстве, вытекающие из акта коррупции.

Конвенция о гражданской ответственности за коррупцию обязывает государства предусмотреть охранительный механизм для государственных служащих. Так, ст. 9 конвенции говорит о том, что каждая сторона предусматривает в своем внутреннем праве надлежащую защиту от любой неоправданной меры служащих, которые имеют серьезные основания подозревать наличие коррупции и добросовестно сообщают о своем подозрении компетентным лицам или властям. Данная мера, безусловно, может способствовать предупреждению и пресечению коррупции в системе государственной службы РФ.

Конвенция о гражданско-правовой ответственности за коррупцию предусматривает сотрудничество государств по вопросам, связанным с гражданским судопроизводством по делам о коррупции: предоставление документов, получение доказательств за рубежом, разграничение юрисдикции, признание и исполнение иностранных судебных решений и судебных расходов в соответствии с положениями международных договоров о международном сотрудничестве в гражданскоправовой и коммерческой сфере, участниками которых они являются, а также в соответствии с их внутренним законодательством.

Любое государство, которое подписало или присоединилось к Конвенции, к моменту вступления ее в силу автоматически становится членом Группы государств против коррупции и осуществляет контроль за исполнением данной Конвенции, руководящих принципов борьбы с коррупцией и других соглашений или правовых документов, принятых Советом Европы в соответствии с Программой действий против коррупции.

Как уже отмечалось, Российская Федерация пока не подписала данную Конвенцию, но стоит отметить, что законодательные акты нашей страны затрагивают некоторые вопросы, урегулированные Конвенцией, но без специального указания на акты коррупции, в частности ст. 168 «Недействительность сделки, не соответствующей закону или иным актам», ст. 169 «Недействительность сделки, совершенной с целью, противной основам правопорядка и нравственности», гл. 59 «Обязательства вследствие причинения вреда» ГК РФ. 
Для предупреждения и пресечения коррупции в системе государственной службы международные организации (ООН, Совет Европы и др.) в качестве дополнительного механизма должны контролировать соблюдение принятых государствами обязательств по борьбе с коррупцией, помогать государствам в разработке соответствующих правовых средств для выполнения взятых ими на себя обязательств. Кроме этого необходимо координировать проекты различных международных организаций, для того чтобы не было непроизвольного дублирования множества принятых конвенций и иных документов, направленных на предупреждение и пресечение коррупции. Дублирование нормативных документов ведет к ослаблению их регулирующего воздействия в сфере публичного управления. Юридические документы должны дополнять друг друга, а не конкурировать в области правовой взаимопомощи, борьбы с коррупцией, а также защиты финансовых интересов государств ${ }^{18}$.

Еще один аспект, на который обращает внимание европейские организации, заинтересованные в борьбе с коррупций является разработка внедрение в практику государственного управления кодексов служебного (этического) поведения государственных служащих. Достаточно широкое распространение и принципиальные содержательные совпадения Кодексов поведения государственных служащих многих государств вызвало объективную необходимость разработки Модельных кодексов поведения государственных служащих ${ }^{19}$. Модельный Кодекс поведения государственных служащих призван служить стандартом при проведении реформы государственной службы в тех странах, где нормы этического поведения чиновников еще не закреплены в нормативных актах ${ }^{20}$.

В этой связи следует обратить внимание на практику Совета Европы в данном направлении. Так, в мае 2000 г. Комитет министров Совета Европы принял рекомендацию № R (2000) 10, в которой предложил государственным органам стран — членов Совета Европы разработать и внедрить в соответствии национальным законодательством и принципами государственного управления Кодексы поведения для государственных служащих. Образцом для этого

18 См.: Государственная служба. Вопросы этики. Зарубежный опыт. - Вып. 5. - М., 1995. - С. 14.

19 См.: Международный кодекс поведения государственных должностных лиц // Борьба с коррупцией: актуальные проблемы законодательного обеспечения. - М., 2002. - С. 195.

20 См.: Оболонский А.В. Размышление о Британском опыте в Российском контексте // Парламентская этика в России. M., 2002. - C. 174. должен послужить Модельный кодекс поведения государственных служащих ${ }^{21}$.

Согласно директивным указаниям Европейский модельный кодекс поведения государственных служащих был разработан междисциплинарной группой по борьбе с коррупцией и является составным элементом в механизме реализации Программы по противодействию коррупции. С самого начал Кодекс поведения государственных служащих касался исключительно государств Евросоюза ${ }^{22}$. Позднее данный документ стал рекомендоваться всем государствам, в которых осуществляются административные реформы, а также реформы государственной службы. По своей структуре Модельный кодекс поведения государственных служащих содержит в себя нормативные предписания, регламентирующие порядок получения чиновником подарков, использование служебной информации, трудоустройство чиновников после увольнения с государственной службы. Следует сказать, что практически все рекомендации учтены в законодательстве о государственной гражданской службе РФ. В настоящее время остается совершенствовать административно-правовой механизм их реализации. Необходимо подчеркнуть, что значение модельного кодекса поведения государственных служащих разработанного экспертами Совета Европы состоит в том, что данный документ определяет проблемные с этической точки зрения места в сфере публичного управления и устанавливает общие требования в вопросе предупреждения и пресечения коррупции в сфере государственной службы ${ }^{23}$.

Значение этических императивов в системе государственной службы достаточно велико как отмечал Б. Чичерин «власть держится не одним присвоенными ей правами, но и нравственным авторитетом. Поэтому служащие, в особенности облеченные властью, обязаны не унижать ее своим поведением, как в общественной, так и в частной жизни. Безнравственные и недостойные чести поступки не совместимы с служебным положением. С целью устранения всяких нареканий и соблазнов, служащим воспрещается иногда и посторонние занятия, как-то ремесла, торговля и т.п.» ${ }^{24}$

\footnotetext{
21 См.: Васильев Д.В., Дробышев П.Ю., Конов А.В. Административная этика как средство противодействия коррупции. - М., 2003. - С. 34.

22 См.: Васильев Д.В., Дробышев П.Ю., Конов А.В. Указ. раб. - С. 34 .

23 См.: там же. - С. 35.

24 См.: Чичерин Б. Курс государственной науки. Ч. І. Общее государственное право. - М., 1894. - С. 368.
} 
Эффективное противодействие коррупции в системе государственной службы невозможно без совершенствования административно-правовых механизмов выявления доходов полученных в результате отмывания денежных средств. В этой связи необходимо ратификация Конвенции Совета Европы «Об отмывании, выявлении, изьятии и конфискации доходов от преступной деятельности и финансирования терроризма». Присоединение нашей страны к данной конвенции позволит вернуть в российское законодательство конфискацию за преступления связанные с легализацией теневых доходов, в частности полученных государственными служащими. Совершенствование законодательства о противодействии легализации доходов полученных преступным путем, обусловлено тем, что «все банки, которые участвуют в отмывании денег, так или иначе связаны с коррупцией».
В заключение исследования международноправовых и европейских средств предупреждения и пресечения коррупции в системе государственной службы РФ позволяет сделать вывод о том, что международное и европейское сообщество стремиться разработать универсальные административно-правовые средства борьбы с коррупцией. Несмотря на унификацию административно-правовых средств направленных на предупреждение и пресечение коррупции в системе государственной службы в международных и европейских документах содержащихся предписания ориентирующие государства на необходимость закрепления антикоррупционных стандартов в своем собственном законодательстве, которое регламентирует государственно-служебные отношения.

\section{Библиографический список:}

1. Богуш Г.И. Понятие коррупции в международном праве и российском законодательстве // Вестник МГУ. Сер 11 . Право. - 2004. — № 2 .

2. Виноградская Т.М. Совершенствование законодательства самая дешевая и эффективная мера снижения коррумпированности // Борьба с коррупцией: актуальные проблемы законодательного обеспечения. - M., 2002.

3. Виноградов В.А. О некоторых международно-правовых аспектах административного права // Административное право: теория и практика. - М., 2002.

4. Васильев Д.В., Дробышев П.Ю., Конов А.В. Административная этика как средство противодействия коррупции. - М., 2003.

5. Государственная служба. Вопросы этики. Зарубежный опыт. - Вып. 5.

6. Гришковец А.А. К вопросу о реформе государственной службы (организационно-правовые аспекты) // Государство и право. — 2012. — № 2.

7. Коррупция и бюрократизм: истоки и пути преодоления. - М., 1998.

8. Левин М., Сатаров Г. Коррупция в России: классификация и динамика // Вопросы экономики. 2012. — №10.

9. Коррупция: политические, экономические, организационные и правовые проблемы. - М., 2001.

10. Максимов С.В. Проблемы и перспективы ратификации Россией Конвенции Совета Европы «Об уголовной ответственности за коррупцию» // Современная уголовная политика в сфере борьбы с транснациональной организованной преступностью и коррупцией. - М., 2002.

11. Поленина С.В. Законотворчество в Российской Федерации. - М., 1996.

12. Раймонд Е. Кендалл. Вклад Интерпола в борьбу с коррупцией // Переводы материалов о практике деятельности правоохранительных органов зарубежных стран: ГИЦ МВД РФ. - М., 2004. — № 28.

13. Сергиенко Л.А. Международно-правовые источники административного права // Административное и информационное право. - М., 2003.

14. Оболонский А.В. Размышление о Британском опыте в Российском контексте // Парламентская этика в России. M., 2002.

15. Сайгитов У.Т. Коррупция как фактор организованной преступности в сфере экономики (криминологический анализ): дис. ... канд. юрид. наук. - Махачкала, 1998.

16. Швец Е.В. Контроль за имущественным состоянием, доходами и обязательствами чиновников (международный и частноправовой аспекты) // Предупреждение организованной и коррупционной преступности средствами различных отраслей права. - М., 2002.

17. Чичерин Б. Курс государственной науки. Ч. І. Общее государственное право. — М., 1894. 


\section{References (transliteration):}

1. Bogush G.I. Ponyatie korruptsii v mezhdunarodnom prave i rossiyskom zakonodatel'stve // Vestnik MGU. Ser 11. Pravo. - 2004. - № 2.

2. Vinogradskaya T.M. Sovershenstvovanie zakonodatel'stva samaya deshevaya i effektivnaya mera snizheniya korrumpirovannosti // Bor'ba s korruptsiey: aktual'nye problemy zakonodatel'nogo obespecheniya. — M., 2002.

3. Vinogradov V.A. O nekotorykh mezhdunarodno-pravovykh aspektakh administrativnogo prava // Administrativnoe pravo: teoriya i praktika. - M., 2002.

4. Vasil'ev D.V., Drobyshev P.Yu., Konov A.V. Administrativnaya etika kak sredstvo protivodeystviya korruptsii. M., 2003.

5. Gosudarstvennaya sluzhba. Voprosy etiki. Zarubezhnyy opyt. - Vyp. 5.

6. Grishkovets A.A. K voprosu o reforme gosudarstvennoy sluzhby (organizatsionno-pravovye aspekty) // Gosudarstvo i pravo. — 2012. — № 2 .

7. Korruptsiya i byurokratizm: istoki i puti preodoleniya. - M., 1998.

8. Levin M., Satarov G. Korruptsiya v Rossii: klassifikatsiya i dinamika // Voprosy ekonomiki. — 2012. — №10.

9. Korruptsiya: politicheskie, ekonomicheskie, organizatsionnye i pravovye problemy. - M., 2001.

10. Maksimov S.V. Problemy i perspektivy ratifikatsii Rossiey Konventsii Soveta Evropy «Ob ugolovnoy otvetstvennosti za korruptsiyu» // Sovremennaya ugolovnaya politika v sfere bor'by s transnatsional'noy organizovannoy prestupnost'yu i korruptsiey. - M., 2002.

11. Polenina S.V. Zakonotvorchestvo v Rossiyskoy Federatsii. — M., 1996.

12. Raymond E. Kendall. Vklad Interpola $\mathrm{v}$ bor'bu s korruptsiey // Perevody materialov o praktike deyatel'nosti pravookhranitel'nykh organov zarubezhnykh stran: GITs MVD RF. — M., 2004. — № 28.

13. Sergienko L.A. Mezhdunarodno-pravovye istochniki administrativnogo prava // Administrativnoe i informatsionnoe pravo. - M., 2003.

14. Obolonskiy A.V. Razmyshlenie o Britanskom opyte v Rossiyskom kontekste // Parlamentskaya etika v Rossii. — M., 2002.

15. Saygitov U.T. Korruptsiya kak faktor organizovannoy prestupnosti v sfere ekonomiki (kriminologicheskiy analiz): Dis. ... kand. yurid. nauk. — Makhachkala, 1998.

16. Shvets E.V. Kontrol' za imushchestvennym sostoyaniem, dokhodami i obyazatel'stvami chinovnikov (mezhdunarodnyy i chastnopravovoy aspekty) // Preduprezhdenie organizovannoy i korruptsionnoy prestupnosti sredstvami razlichnykh otrasley prava. - M., 2002.

17. Chicherin B. Kurs gosudarstvennoy nauki. Ch. I. Obshchee gosudarstvennoe pravo. — M., 1894. 